\title{
Overexpression of the arginine-rich carboxy-terminal region of U1 snRNP 70K inhibits both splicing and nucleocytoplasmic transport of mRNA
}

\author{
Joelle M.-J. Romac ${ }^{1}$ and Jack D. Keene ${ }^{2}$ \\ Department of Microbiology, Duke University Medical Center, Durham, North Carolina 27710 USA
}

Transient transfection of the U1 snRNP $70 \mathrm{~K}$ protein into COS cells induced nuclear reorganization and redistribution of the splicing factor SC-35, whereas hnRNP proteins were not affected. Correspondingly, splicing and nucleocytoplasmic transport of a coexpressed mRNA substrate was reduced by overexpression of U1-70K. The carboxy-terminal portion of U1-70K-encompassing repeats of Arg/Ser, Arg/Glu, and Arg/Asp localizes to the nucleus independently of U1 RNA and was responsible for these inhibitory effects. This region of U1-70K contains amino acid residues similar to those found in splicing factors SC-35, U2AF, su( $\left.w^{a}\right)$, and in other SR proteins suggesting that U1-70K protein may serve as a focus of assembly for functional components of the splicing/transport machinery. These findings are compatible with models that propose that direct interaction between U1-70K and SR proteins play a regulatory role in early events of spliceosome assembly.

[Key Words: Ul snRNP 70K protein; splicing; nucleocytoplasmic transport; mRNA; SR proteins]

Received November 7, 1994; revised version accepted April 14, 1995.

The splicing of RNA polymerase II transcripts is one of a series of processive events in the nucleus that culminates with export of mature mRNA to the cytoplasm (for review, see Moore et al. 1993). Splicing occurs in the multicomponent spliceosome, which consists of mRNA substrates, small nuclear ribonucleoprotein (snRNP) particles, non-snRNP splicing factors, and numerous additional factors. The absence of unspliced messages in the cytoplasm suggests that mRNA transport is coupled to the splicing machinery in the nucleus.

Immunofluorescence has shown that snRNP components are present in the nucleoplasm of interphase nuclei and exhibit a speckled pattern of staining (Lerner et al. 1981). Recently, certain components of the splicing machinery, such as the splicing factor SC-35 $(\mathrm{Fu}$ and $\mathrm{Ma}$ niatis 1990) and the U1 and U2, RNAs have been localized in the speckles (Huang and Spector 1992). These speckles appear to be the interchromatin granules and perichromatin fibers identified previously by electron microscopy (Fakan et al. 1984; Spector et al. 1991). Three-dimensional reconstruction imaging suggests that these structures form a lattice extending from the nucleolar surface to the nuclear envelope (Spector 1990). Two conflicting models have been proposed for the function

\footnotetext{
${ }^{1}$ Present address: Department of Medicine, Duke University Medical Center, Durham, North Carolina 27710 USA.

${ }^{2}$ Corresponding author.
}

of the speckles (for review, see Rosbash and Singer 1993). The first model proposes that the speckles are sites at which splicing occurs and is based on the following findings: Microinjected $\beta$-globin pre-mRNA localizes to the speckles (Wang et al. 1991); and poly(A) RNAs, detected by in situ hybridization, localize in discrete domains that encompass or are in close proximity to speckles (Carter et al. 1993; Xing et al. 1993). A second model suggests that speckles are storage facilities for splicing components. This is based on the observation that heterogenous nuclear RNP (hnRNP) proteins and newly synthesized RNAs are found localized in perichromatin fibrils but not in interchromatin granules (Fakan et al. 1984; Spector 1990|. Furthermore, antibodies reactive with nascent RNA polymerase II transcripts that are BrUTP labeled failed to colocalize with the splicing factor SC-35 in speckles (Wansink et al. 1993). Thus, the exact function of these speckles in nuclear RNA metabolism has yet to be determined.

The U1-70K protein is a component of Ul snRNP particles (Billings and Hoch 1984; Petterson et al. 1984) that are involved in pre-mRNA splicing via base-pairing at intron/exon junctions (for review, see Green 1986; Steitz et al. 1988; Reich et al. 1992). However, a functional role for U1-70K in splicing has not been demonstrated, in part, because it has not been possible to express the protein in bacteria (C.C. Query and J.D. Keene, unpubl.). The U1-70K protein harbors a single RNA-binding do- 
U1 snRNP-70K affects pre-mRNA splicing and transport

main encompassing its RNA recognition motif (RRM) that specifically binds the $5^{\prime}$ stem-loop of U1 RNA (Query et al. 1989a,b). The second half of U1-70K contains two highly charged arginine-rich regions (Theissen et al. 1986; Query et al. 1989a) that ari believed to possess trans-acting functions (for review, see Keene and Query 1991). Similar charged regions, termed RS (arginine-serine rich), have been noted in a number of proteins, including splicing factors $\mathrm{U}^{2} \mathrm{AF}^{65}$ (Zamore et al. 1992), U2AF ${ }^{35}$ (Zhang et al. 1992), and members of the SR family (Zahler et al. 1992, 1993), which include SC-35 (Fu and Maniatis 1990) and ASF/SF2 proteins /Ge et al. 1991; Krainer et al. 1991). Drosophila factors tra, tra-2, and $\operatorname{su}\left(w^{a}\right)$, which are involved in regulated alternative splicing, also contain similar RS sequences (Baker 1989; Chou et al. 1987; Zachar et al. 1987).

Wu and Maniatis (1993) and Kohtz et al. (1994) demonstrated recently that $\mathrm{U} 1-70 \mathrm{~K}$ can interact directly with the splicing factors SC-35 and ASF/SF2 in vitro. In this study we have used transient transfection to explore the effect of U1-70K and its arginine-rich domain in vivo. By monitoring epitope-tagged proteins in COS cells our studies revealed that overexpression of $\mathrm{U} 1-70 \mathrm{~K}$ induced a nuclear reorganization involving SC-35 that correlated with an inhibitory effect on both splicing and nucleocytoplasmic transport of RNA polymerase II transcripts. Expression of recombinant fragments of $\mathrm{Ul}-70 \mathrm{~K}$ revealed that the carboxy-terminal portion of the protein containing the highly redundant Arg-rich sequences was responsible for these effects. These data are compatible with a model of direct interaction between Ul-70K and SR proteins in which overexpression of the U1-70K RD/ $\mathrm{RE} / \mathrm{RS}$ regions can result in a regulatory imbalance and functional distortion of splicing and transport.

\section{Results \\ Redistribution of nuclear splicing factors following overexpression of the U1-70K protein}

Immunofluorescence experiments of transiently transfected COS cells have shown previously that the overexpressed U1-70K, but not U1-A, protein exhibited a unique staining pattern (Romac et al. 1994). In these studies it was observed that U1-70K protein concentrated in very large speckled loci within the nucleoplasm, which corresponded to distinct structures under phase-contrast microscopy. In this study we tried to determine which region of the protein was responsible for this nuclear staining pattern, by overexpressing g10 epitope-tagged constructs of U1-70K in COS cells. One construct harbored the full-length $\mathrm{U} 1-70 \mathrm{~K}$ protein, another contained the amino-terminal half of the protein encompassing the U1 RNA-binding domain (Query et al. 1989al, and a third construct lacked the RNA-binding domain (Fig. 1A). The latter construct encompasses two redundant Arg-rich regions, termed RD/RE/RS, of Ul$70 \mathrm{~K}$ that resemble sequences present in other regulated splicing factors (for review, see Keene and Query 1991). Although the three expressed proteins were localized in the nucleoplasm of interphase cells, clear differences in nuclear staining patterns were apparent (Fig. 2). The fulllength (U1-70K wild type) and the carboxy-terminal fragment $[\mathrm{U} 1-70 \mathrm{~K}(161-437)]$, when expressed to similar levels, both induced formation of loci in the nucleoplasm, whereas the amino-terminal fragment [U1$70 \mathrm{~K}(1-216)]$ stained the nucleoplasm in a homogeneous manner. Double immunofluorescence was performed on these cells using anti-g10 and anti-SC-35 (Fig. 2A) or anti-g10 with anti-hnRNP-C (Fig. 2B). The localization
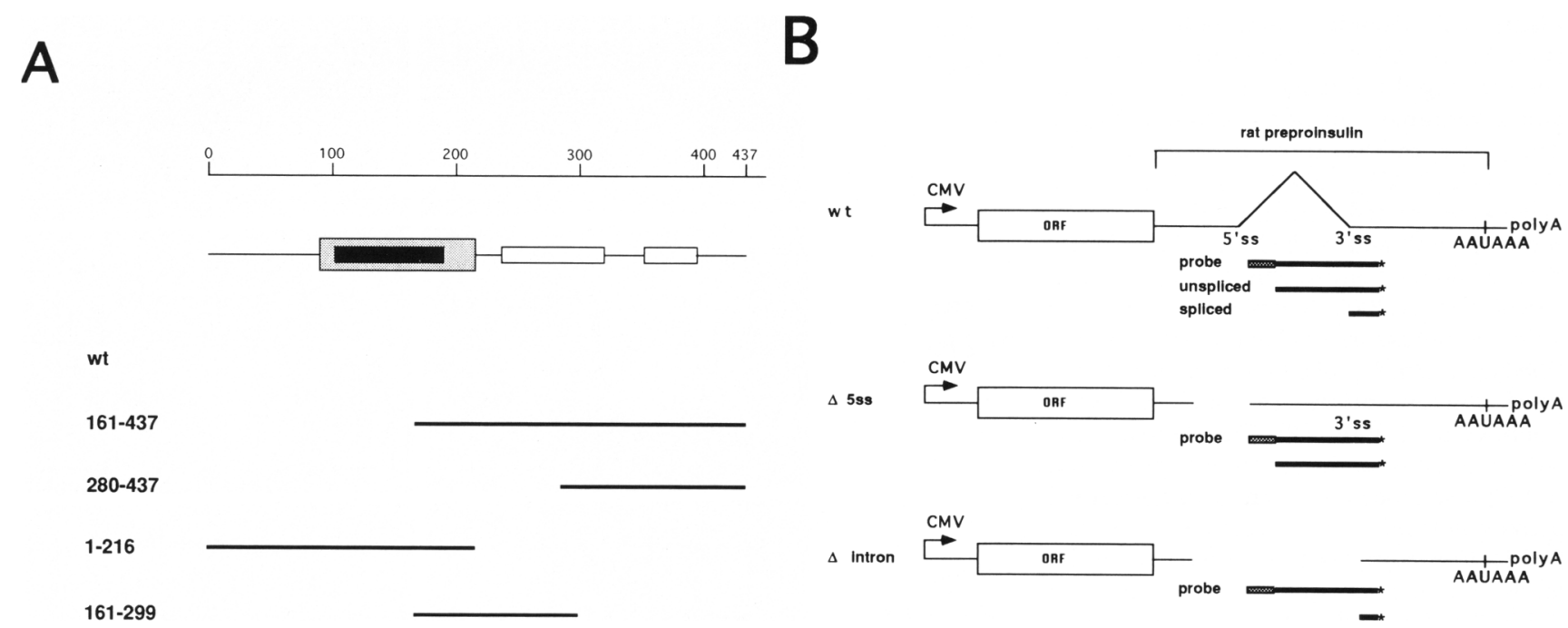

Figure 1. (A) Schematic of the U1-70K protein and portions expressed from the recombinant U1-70K constructs using the pBC vector. The U1-70K Ul RNA-binding domain (shaded box) encompasses an RRM (black box) and two regions rich in Arg/Asp, Arg/Glu, and Arg/Ser (open boxes). (B) Dual constructs used in this study that express ORFs of U1-70K, portions of U1-70K, or IL-2 control protein, each are attached to an internal pre-mRNA reporter construct (PPI). 
of the SC-35 and the hnRNP-C proteins was examined because both have been reported to be involved in premRNA splicing (Choi et al. 1986; Fu and Maniatis 1992).
SC-35 was present in the large nuclear loci when either Ul-70K or its deletion mutant 161-437 was overexpressed (Fig. 2A). The hnRNP-C protein, however, did

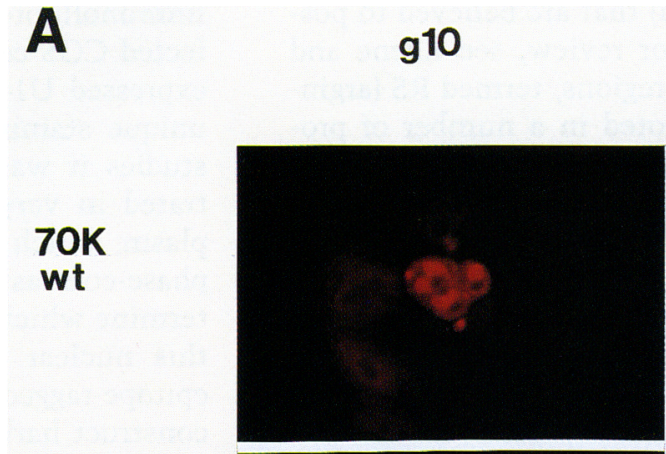

Figure 2. Double immunofluorescence staining of COS cells transfected with epitope-tagged full-length (g10-Ul-70K), an amino-terminal portion $[\mathrm{g} 10-\mathrm{U} 1-70 \mathrm{~K} / 1-$ $216)$, or a carboxy-terminal portion [g10 U1-70K(161-437)] cDNA.|A) Transfected cells were reacted with the rabbit anti-g10 serum (1:200) and probed with an affinitypurified donkey anti-rabbit conjugated with Texas Red (1:200). Samples were reacted with the mouse monoclonal anti-SC-35 antibody $(5 \mu \mathrm{g} / \mathrm{ml})$, probed with an affinity-purified donkey anti-mouse conjugated with fluorescein $\{1: 200)$. (B) Transfected cells were reacted with the rabbit anti-g10 serum (1:200) and probed with an affinity-purified donkey anti-rabbit conjugated with TexasRed (1:200). Samples were reacted with the mouse monoclonal anti-hnRNP-C antibody (1:5000) and probed with an affinity-purified donkey anti-mouse conjugated with fluorescein $(1: 200)$. Photographs were taken on a Zeiss Axioskop microscope with a $100 \times$ objective and recorded on Ektachrome 400.
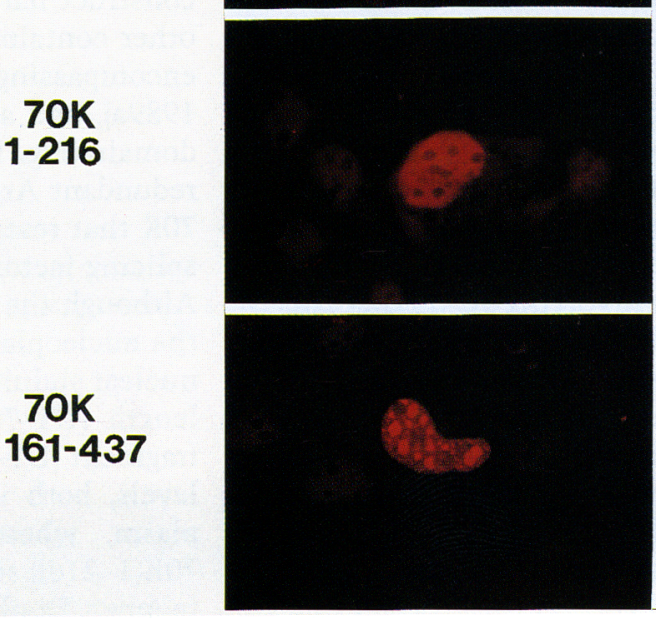

B

$70 K$
$161-437$

\section{g10}
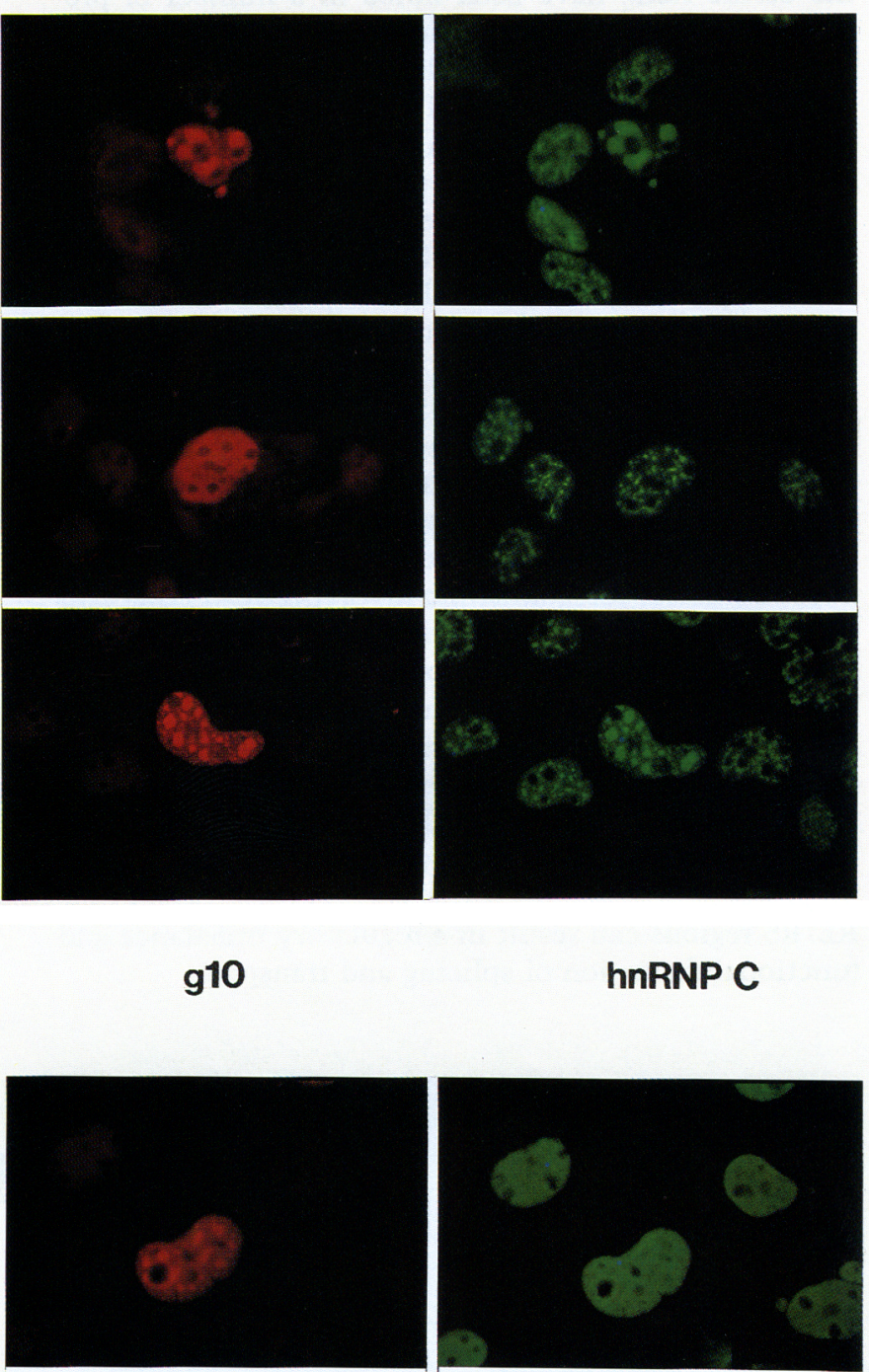

hnRNP C

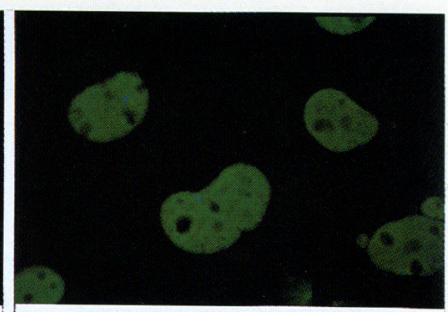

$70 \mathrm{~K}$

1-216
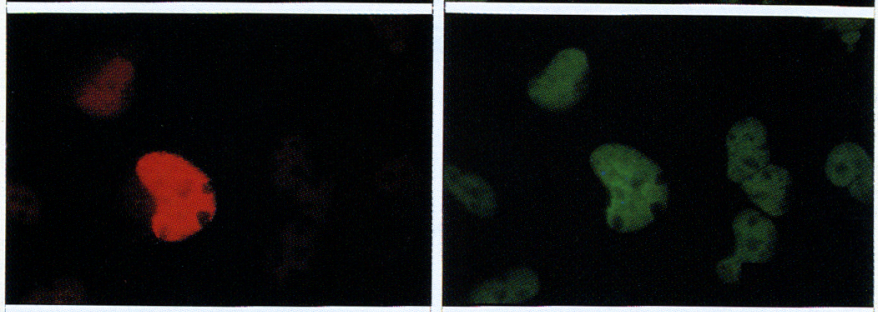

70K

161-437

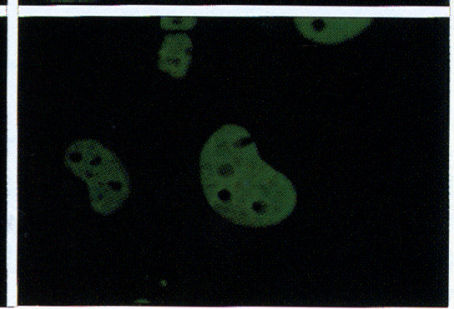


not redistribute following overexpression of $\mathrm{Ul}-70 \mathrm{~K}$ or its 161-437 mutant (Fig. 2B). No redistribution of SC-35 was observed in cells transfected with Ul-70K mutant construct containing amino acids 1-216 or other unrelated proteins (Fig. 2A, middle row; data not shown).

Overexpression of U1-70K inhibits splicing and nucleocytoplasmic transport of polymerase II transcripts

Because U1-70K expression affected the nuclear localization of the splicing factor SC-35 it became important to follow the fate of spliced and unspliced RNA polymerase II transcripts in transfected cells. We utilized a construct containing the open reading frame (ORF) of Ul$70 \mathrm{~K}$, followed by a fragment of the rat preproinsulin gene (PPI reporter) inserted into the 3 '-untranslated region (UTR) of U1-70K cDNA and containing an intron flanked by two exons (Fig. 1B). Transcription of this chimeric DNA was driven by the cytomegalovirus (CMV) promoter and yielded a g10 epitope-tagged U1-70K protein. The presence of the intron allowed us to follow the fate of the splicing substrates in the subpopulation of COS cells that were transiently transfected. We expressed two other constructs that were modified in the PPI portion of the chimeric DNA to investigate the nucleocytoplasmic transport of the chimeric transcript: One lacked the $5^{\prime}$ splice site (Fig. $1 \mathrm{~B}, \Delta 5^{\prime} \mathrm{ss}$ ), and the other lacked the intron sequence (Fig. 1B, $\Delta$ intron). DNA probes designed to encompass the intron-exon junction at the 3 ' splice site allowed us to discriminate among the unspliced, the spliced, and the intronless mRNA (Fig. 1B). Because it was expressed only in transfected cells, the PPI construct served as an internal indicator of the effect of U1-70K fragments on splicing. Constructs expressing Ul-70K protein deletion fragments were also used, as was a negative control expressing the interleukin-2 (IL-2) protein (Cullen 1986).

Constructs designed to express the tagged U1-70K protein from an mRNA transcript containing either a whole intron [Fig. 3A(a),B, lanes 2,3)], an intron lacking the $5^{\prime}$ splice site [Fig. $3 \mathrm{~A}(\mathrm{~b}), \mathrm{B}$, lanes 4,5$]$, or lacking the whole intron [Fig. $3 \mathrm{~A}(\mathrm{C}), \mathrm{B}$, lanes 6,7$]$ were transfected into COS cells. The transcript expressing the IL-2 protein was used as an internal control [Fig. $3 \mathrm{~A}|\mathrm{~d}|, \mathrm{B}$, lanes $8,9]$. The predicted transcripts and resulting $S 1$ nucleaseprotected fragments are depicted in Figure 3A. Nuclear and cytoplasmic RNAs were isolated, and the distribution of the messages was analyzed by S1 nuclease protection as described in Materials and methods and shown in Figure 3B. The expression of the epitope-tagged $\mathrm{Ul}-70 \mathrm{~K}$ protein products in these experiments was verified by Western blotting (Fig. 3C).

Our results show that expression of wild-type U1-70K caused a decrease in the ratio of cytoplasmic to nuclear RNA. It affected two steps in mRNA processing: one was splicing, and the other was nucleocytoplasmic transport of mRNA. Inhibition of splicing was revealed by an increase in the amount of unspliced nuclear message (band $\mathrm{u}$ in Fig. 3B). The $\mathrm{u}$ band of lane 2 has an area of 2.374
AUxmm (absorbance unit $\times \mathrm{mm}$ ), and the $\mathrm{u}$ band of lane 6 has an area of 2.494 AUxmm, which should be compared to the control, which is the $\mathrm{u}$ band of lane 8; this band has an area of $0.628 \mathrm{AUxmm}$ (see Materials and methods). Note that transcripts expressed from single plasmid [Fig. 3A/a)] or from two plasmids [Fig. 3A(c)] were affected similarly. Inhibition of nucleocytoplasmic transport of spliced mRNAs could be measured by comparing the ratio of cytoplasmic over nuclear spliced mRNA (Fig. 3B, band s). Compare the ratio for the $s$ band of lane 7 over the s band of lane 6, which was 1.52 (U1$70 \mathrm{~K}$ ), while the ratio of the s band of lane 9 over the s band of lane 8 was 4.86 (control). The mRNA derived from the U1-70K construct containing the deleted $5^{\prime}$ splice site could be transported to the cytoplasm (Fig. 3B, lane 5) in higher levels and at a higher ratio than the mRNA derived from the Ul-70K construct containing the full intron (Fig. 3B, lane 3, band s). Quantitation of the bands gave a ratio of cytoplasmic over nuclear RNA of 0.62 for the deleted 5' splice site mRNA (Fig. 3B, lane 5 over lane 4 ) and a value of 0.26 for the intron-containing transcript (Fig. 3B, lane 3 over lane 2, bands s and $\mathrm{u}$ ). This suggested that U1-70K overexpression affected splicing and transport of mRNAs in a cumulative manner. Because of the location of the deletion in the $5^{\prime}$ splice site that spans beyond the probe, the size of the protected fragment for the $5^{\prime}$ splice site-deleted transcript was the same as the wild-type transcript /see Fig. 1B). Inhibition of transport can also be deduced by comparison of the cytoplasmic versus nuclear RNA ratio of the $5^{\prime}$ splice site-deleted transcript coding for U1-70K (lane 5 over lane 4 ), which is 0.62 , and the control transcript (lane 9 over lane 8 ), which is 3.78 . The latter ratio was calculated by combining both unspliced and spliced peak areas. It is possible that the effect of U1-70K on transport could result from a secondary consequence on the steady state of mRNA encoding a cellular factor directly involved in mRNA transport.

\section{Inhibition of nucleocytoplasmic mRNA transport is dependent on plasmid concentration and correlates with the size of nuclear loci}

To examine whether the effects of U1-70K were dose dependent, we varied the amount of pBC-U1-70K plasmid (Fig. 4). To maintain a constant amount of input DNA $(5 \mu \mathrm{g})$, a compensating amount of control plasmid DNA (pBC-IL-2) was added. Plasmids pBC-Ul-70K and pBC-IL-2 are very similar in that they share a common vector construct and contain the same PPI reporter gene. S1 analysis of RNA from cells transfected with $5 \mu \mathrm{g}$ (Fig. $4 \mathrm{~A}$, lanes 1,2 ) or $0.5 \mu \mathrm{g}$ (Fig. 4A, lanes 3,4 ) of $\mathrm{pBC}-\mathrm{Ul}$ $70 \mathrm{~K}$ confirmed that expression of the protein affected transport of spliced RNAs from the nucleus to the cytoplasm (Fig. 4A, cf. lanes 2, 4, and 8). However, when the cells were transfected with $0.1 \mu \mathrm{g}$ of $\mathrm{pBC}-\mathrm{Ul}-70 \mathrm{~K}$ plasmid, the amount of mRNA transported to the cytoplasm (Fig. 4A, lane 6) was comparable to the amount present in the cytoplasm of control transfected cells (Fig. 4A, lane 81. Interestingly, immunofluorescence studies 
A

a

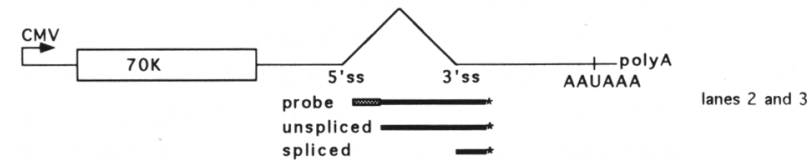

b

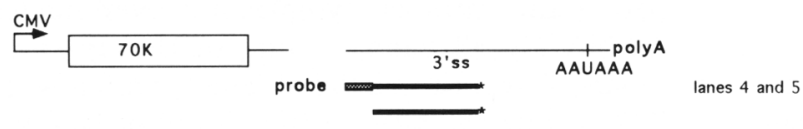

C

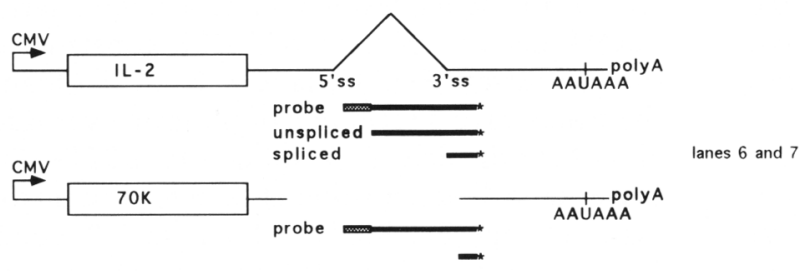

d

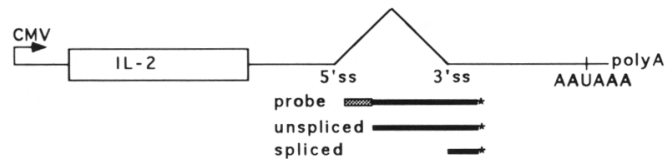

B

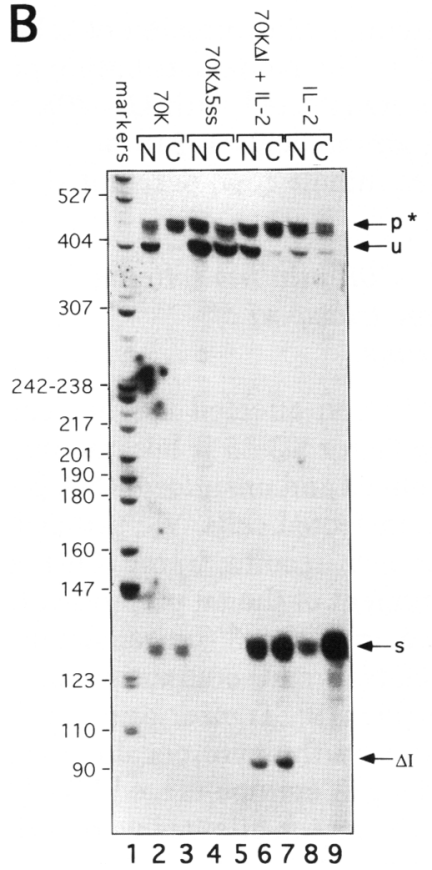

Figure 3. Overexpression of Ul-70K inhibits splicing and nucleo-cytoplasmic transport of PPI reporter transcripts. $(A)$ Schematics of the transcripts analyzed in $B$ and $C$. COS cells (100-mm dishes) were transfected with either $5 \mu \mathrm{g}$ of Ul-70K $(a), 5 \mu \mathrm{g}$ of Ul-70K- $\Delta 5$ 'ss $(b), 0.5$ $\mu \mathrm{g}$ of Ul-70K- $-\Delta \mathrm{I}$ and $4.5 \mu \mathrm{g}$ of IL-2 $(c)$, or $5 \mu \mathrm{g}$ of IL-2 $(d)$. The size of each PPI probe and its protected fragments are depicted. The open boxes represent the ORF for Ul-70K, fragments of Ul-70K, or IL-2. (B) S1 nuclease protection analysis of PPI transcripts from constructs described in

$A:(a)$ lanes 2,$3 ;(b$ lanes 4,$5 ;(c)$ lanes 6,$7 ;(d)$ lanes 8,9 . Protected nuclear (lanes 2,4,6,8) and cytoplasmic (lanes 3,5,7,9) RNA fragments were resolved by electrophoresis in $7 \mathrm{M}$ urea-5\% polyacrylamide gel and analyzed by autoradiography with Kodak XAR film. Probe $\left(\mathrm{p}^{*}\right)$ unspliced $\langle\mathrm{u})$, spliced $(s)$, and intronless $\langle\Delta \mathrm{I}\rangle$ transcripts are indicated by arrows. $|C|$ Corresponding Western blot of cell extracts showing production of protein products derived from transcripts of cDNA described in $A)$ : $(a)$ lane $1 ;(b)$ lane $2 ;(c)$ lane $3 ;(d)$ lane 4 using the anti-g10 serum $(1: 5000)$ and the ECL reagents (Amersham).

showed that cells transfected with $0.1 \mu \mathrm{g}$ of $\mathrm{Ul}-70 \mathrm{~K}$ cDNA plasmid did not contain the Ul-70K-induced nuclear loci shown above [Fig. 4B(b); Romac et al. 1994]. However, when cells were transfected with $5 \mu \mathrm{g}$ of the U1-70K plasmid cDNA the large loci were readily observed [Fig. 4B(a); see Fig. 2].

The carboxy-terminal half of U1-70K is sufficient for inhibiting $m R N A$ processing

To determine the region of the U1-70K protein that was responsible for the inhibitory effects described above, we carried out $\mathrm{S} 1$ analysis of the chimeric transcript following expression of fragments of $\mathrm{U} 1-70 \mathrm{~K}$. As shown previously (Romac et al. 1994) and in Figure 2, the protein fragment containing the U1 RNA-binding domain (1216) was transported to the nucleus. However, unlike the full-length Ul-70K, this protein fragment did not significantly affect the ratio of cytoplasmic message over the nuclear message (Fig. 5). The ratio of the bands present in lane 5 over the bands present in lane 4 was $0.85[\mathrm{U} 1-70 \mathrm{~K}(1-216)]$, whereas the ratio of the bands present in lane 3 over the bands present in lane 2 was 0.24 (U1-70K). When the carboxy-terminal protein fragment $(161-437)$ was expressed in COS cells, the ratio of spliced message in the cytoplasm was reduced (Fig. 6A, band $s \mid$. Thus, the ratio of the s band of lane 2 over the $s$ band of lane 1 was 0.63 [U1-70K(161-437)] whereas the ratio of the $s$ band of lanes 6 over the $s$ band of lane 5 was 2.40 (control), which is similar to that with wild-type U1-70K (Fig. 3B, s band of lanes 2,3). A shorter fragment (280-437) did not reduce the ratio of cytoplasmic over nuclear-spliced message (ratio of the s band of lane 4 over the s band of lane 3 was 2.66 ) and behaved like the control protein (ratio of 2.40). This result could be attributable to the fact that this fragment remained in the cytoplasm (Romac et al. 1994). The presence of the proteins in the transfected cells was verified by Western blot analysis (Fig. 6B). In experiments analogous to those involving the full-length $\mathrm{U} 1-70 \mathrm{~K}$, we found that the construct 


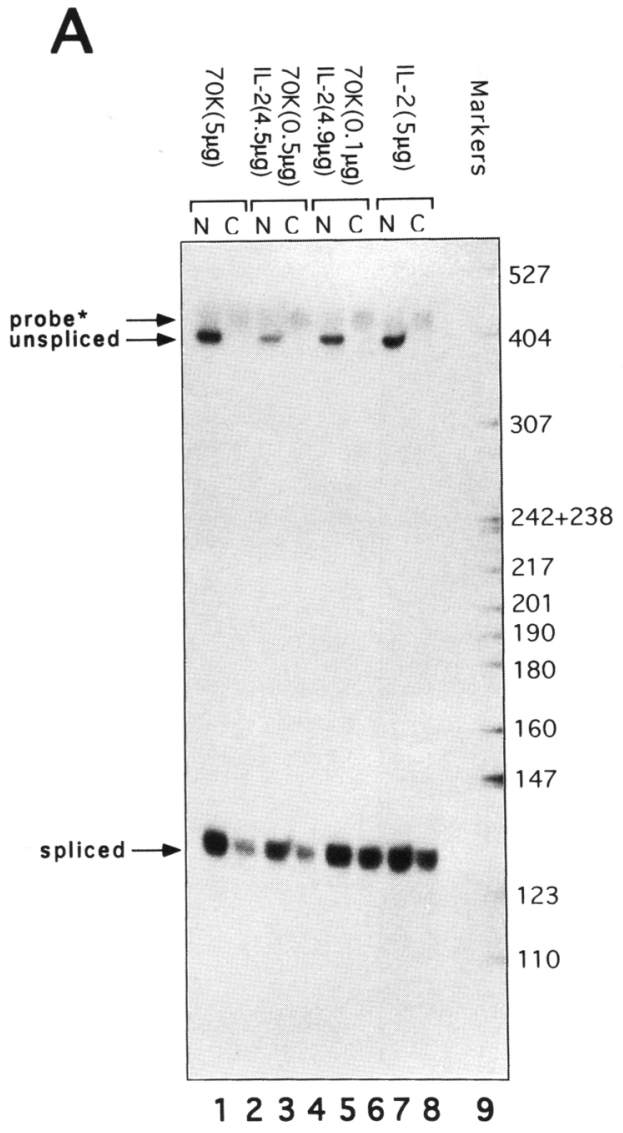

B

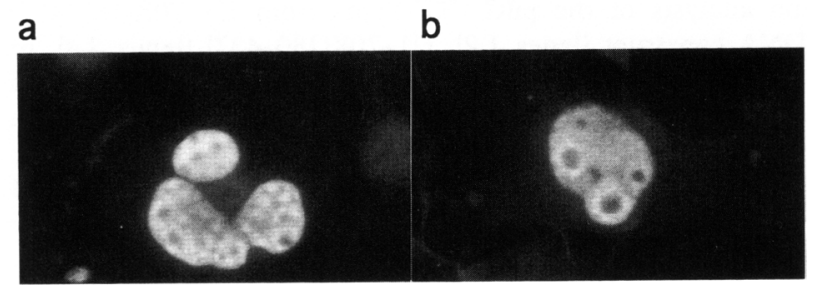

Figure 4. The inhibition of nucleocytoplasmic mRNA transport by $\mathrm{U} 1-70 \mathrm{~K}$ is dependent on the plasmid concentration and correlates with the presence of nuclear loci. $|A| \operatorname{COS}$ cells were transfected with either $5 \mu \mathrm{g}$ of Ul-70K (lanes 1,2$), 0.5 \mu \mathrm{g}$ of $\mathrm{U} 1-70 \mathrm{~K}$ and $4.5 \mu \mathrm{g}$ of IL-2 (lanes 3,4 ), $0.1 \mu \mathrm{g}$ of U1-70K and 4.9 $\mu \mathrm{g}$ of IL-2 (lanes 5,6$)$, or $5 \mu \mathrm{g}$ of IL-2 (lanes 7,8$)$. The concentration of the plasmid DNA in each dish was constant at $2.5 \mu \mathrm{g} /$ $\mathrm{ml}$. Protected nuclear (lanes 1,3,5,7) and cytoplasmic (lanes $2,4,6,8)$ PPI RNA fragments were analyzed as in Fig. 3B. $(B)$ Immunofluorescence staining of COS cells transfected with $0.25 \mu \mathrm{g}$ of $\mathrm{U} 1-70 \mathrm{~K}$ at a concentration of $2.5 \mu \mathrm{g} / \mathrm{ml}(a)$ or $0.05 \mu \mathrm{g}$ of U1-70K and $0.2 \mu \mathrm{g} \mathrm{IL-2} \mathrm{as} \mathrm{a} \mathrm{control} \mathrm{plasmid} \mathrm{for} \mathrm{a} \mathrm{final} \mathrm{DNA}$ concentration of $2.5 \mu \mathrm{g} / \mathrm{ml}(b)$.

U1-70K(161-437) affected splicing (Fig. 7B, cf. lane 1 with 5, unspliced) and transport (Fig. 7B, cf. lane 2 with lane 6, spliced) of the transcripts in a manner similar to the full-length $\mathrm{U} 1-70 \mathrm{~K}$ protein.

It was shown previously that the carboxy-terminal half of Ul-70K, when expressed alone, does not associate with Ul snRNPs in the nucleus (Romac et al. 1994). Therefore, it is likely that the free overexpressed Ul$70 \mathrm{~K}$ protein is sufficient for inducing the inhibition of mRNA splicing and transport that we describe in this paper.

\section{Effect of U1-70K expression on intronless mRNAs}

To examine the effect of the overexpression of U1-70K on nucleocytoplasmic transport alone, we analyzed the distribution of the mRNAs lacking the intron (Fig. 8A) or lacking the 5'-splice site (Fig. 8B). The amino-terminal fragment U1-70K(1-216) was used as a control because this protein fragment did not affect mRNA transport (Fig. 5). When the U1-70K amino-terminal fragment was expressed, the transcript was transported to the cytoplasm and only a small amount was detected in the nucleus (Fig. 8A, cf. lanes 4 and 5; Fig. 8B, cf. lanes 5 and 6), whether the transcript lacked the 5 '-splice site (Fig. 8A) or the complete intron (Fig. 8B). On the other hand, tran-

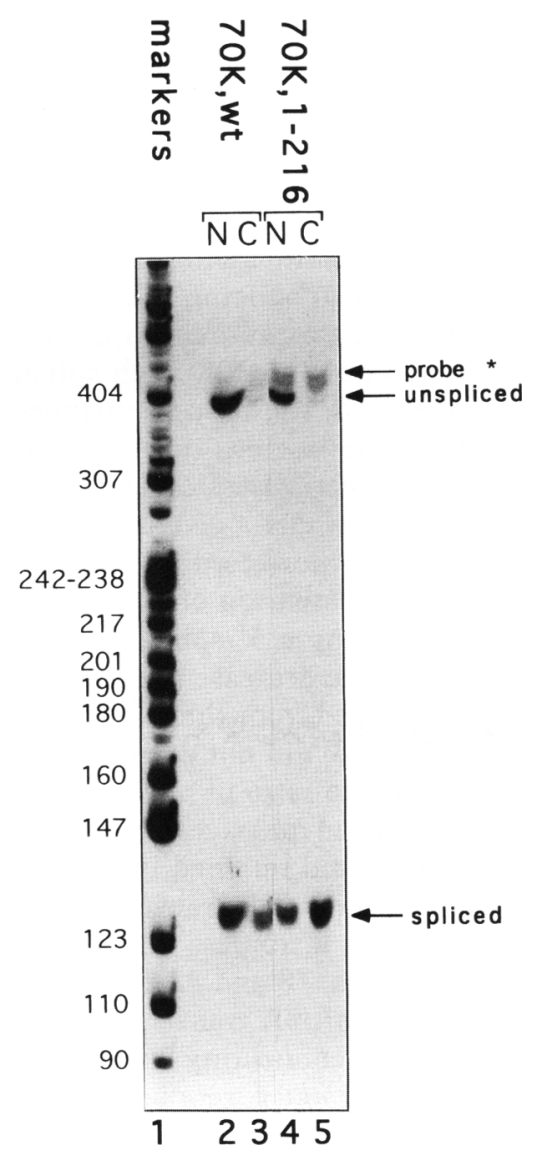

Figure 5. The amino-terminal half of $\mathrm{U} 1-70 \mathrm{~K}$ does not cause inhibition of mRNA processing. $\mathrm{S} 1$ nuclease protection analysis of the $\mathrm{pBC}$ transcripts from a full-length $\mathrm{U} 1-70 \mathrm{~K}$ construct (lanes 2,3), or its amino-terminal fragment U1-70 (1-216) (lanes 4,5). Protected nuclear (lanes 2,4) and cytoplasmic (lanes 3,5) RNA fragments were analyzed as in Fig. 3B. 
scripts expressing wild-type U1-70K protein distributed equally between the nucleus and the cytoplasm (Fig. 8A, cf. lanes 2 and 3; Fig. 8B, cf. lanes 3 and 4). We conclude that U1-70K affects nucleocytoplasmic transport of intronless messages that are normally transported to the cytoplasm.

Transport of mRNA transcripts can be affected by a subregion of $U 1-70 \mathrm{~K}$ containing the $R D / R E / R S$ sequences

Having shown that the carboxy-terminal half of U1-70K was responsible for inhibition of transport, we were interested in determining whether a shorter protein fragment containing mainly the Arg/Ser residues can affect mRNA transport. Figure 9 shows that transfection of the carboxy-terminal region representing residues 161-299 significantly enhanced the amount of intronless mRNA retained in the nucleus (cf. lanes 1 and 3). The results also indicate that the U1-70K(161-299) portion either enhanced expression or helped stabilize its own transcript in the nucleus. Double indirect immunofluorescence indicated that this construct could not induce a redistribution of SC-35 in transfected cells but displayed a similar staining pattern as the 1-216 amino acid portion (identical to pattern shown in Fig. 2A, center).

\section{Discussion}

We have demonstrated that the carboxy-terminal half of the U1-70K protein encompassing the two $\mathrm{RD} / \mathrm{RE} / \mathrm{RS}$ regions was able to affect splicing and transport of a reporter mRNA following expression in COS cells. Interference of this region of U1-70K with splicing was revealed by an increase in the ratio of unspliced reporter message present in the nucleus over that found in the cytoplasm following overexpression of the protein (Figs. 1B, 3B, and 7B). A direct effect of U1-70K on nucleocytoplasmic transport of reporter mRNA was evidenced by an increase in nuclear retention of both intronless transcripts and those lacking a $5^{\prime}$ splice site (Figs. 7B and $8 \mathrm{~A}, \mathrm{~B} \mid$. Unexpectedly, the decrease in cytoplasmic PPI reporter message expressed from the full-length wild-type U1-70K protein (Fig. 1B) did not correlate with a corresponding increase in the ratio of nuclear message. This suggested that the spliced message, when expressed from the full-length cDNA and retained in the nucleus, was degraded. On the other hand, transcripts containing a deleted $5^{\prime}$ splice site or intronless cDNAs remained intact in the nucleus (Figs. $7 \mathrm{~B}$ and $8 \mathrm{~A}, \mathrm{~B}$ ).

Newly synthesized mRNA transcripts are thought to be anchored to an interconnecting lattice in association with the nuclear matrix and extending from the nucleolus to the nuclear pores (Spector 1990). Splicing may occur along this lattice, and processed mRNAs migrate toward the nuclear pores. One interpretation of our results is that overexpression of U1-70K disrupts the equilibrium between components of splicing and transport, thus partially blocking splicing and retaining the spliced message in the nucleus. Ultrastructurally, this correlates

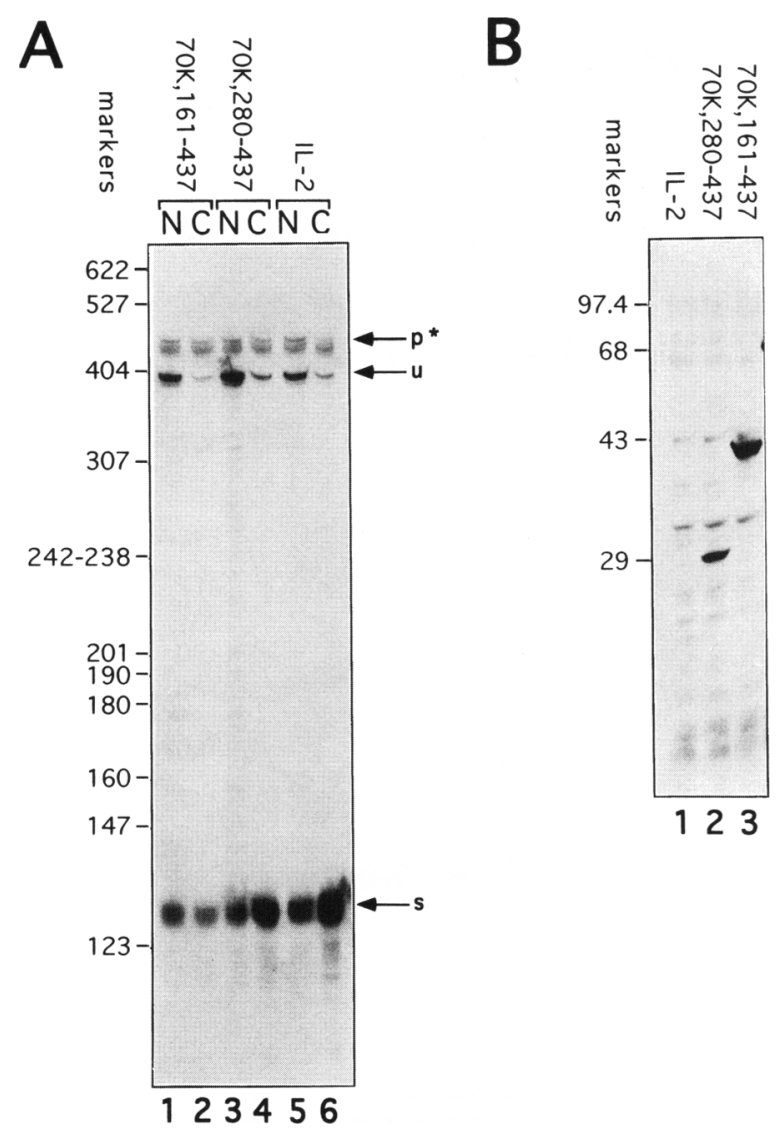

Figure 6. The carboxy-terminal half of $\mathrm{U} 1-70 \mathrm{~K}$ is responsible for the inhibition of mRNA processing. $(A) \mathrm{S} 1$ nuclease protection analysis of the pBC transcripts from U1-70K(161-437) cDNA construct (lanes 1,2), Ul-70K $(280-437$ ) (lanes 3,4), or control cDNA (lanes 5,6). Protected nuclear (lanes 1,3,5) and cytoplasmic (lanes $2,4,6$ ) RNA fragments were analyzed as in Fig. 3B. Probe $\left(p^{*}\right)$, unspliced $\langle u|$, and spliced $(s)$ transcripts are indicated by arrows. $(B)$ Corresponding Western blot analysis of cell extracts obtained from transfected cells using anti-g10 serum as in Fig. 3C.

with a decrease in the number of nuclear speckles and an increase in the size of the remaining speckles as if they had coalesced. This is consistent with our observation that U1-70K expression induces a redistribution of SC35 in the nucleus. Recently, O'Keefe et al. (1994) reported that microinjection of complementary U1 and U6 oligonucleotides or antibodies known to inhibit splicing in vitro induced similar modification of the number and shape of nuclear speckles. Interestingly, Gui et al. (1994), have demonstrated that a kinase able to phosphorylate SC-35 induced disassembly of nuclear speckles when added to permeabilized HeLa cells. It is possible that dephosphorylation of SC-35 would lead to the reverse situation in which nuclear speckles coalesce. U1-70K can also be phosphorylated (Wooley et al. 1983) in its $\mathrm{RD} / \mathrm{RE} / \mathrm{RS}$ domain (Woppmann et al. 1990) possibly by the same kinase. Interestingly, in our transfection experiments the overexpressed U1-70K failed to become 

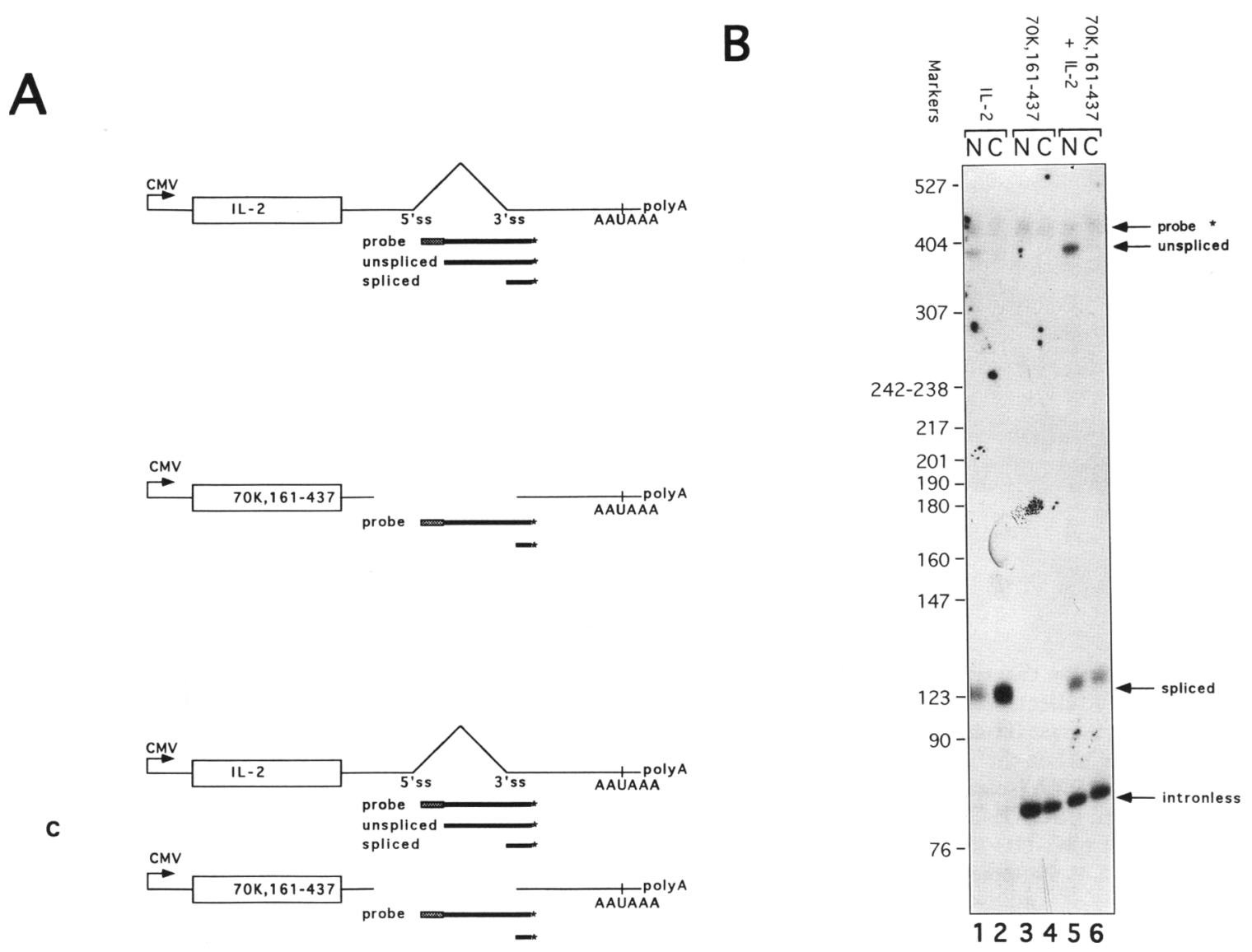

Figure 7. The effect of $U 1-70 \mathrm{~K}(161-437)$ on splicing and transport can be detected in diverse transcripts. $(A)$ Schematics of the transcripts expressed in COS cells transfected with $5 \mu \mathrm{g}$ of IL-2 plasmid $(a), 5 \mu \mathrm{g}$ of U1-70K(161-437)- $\Delta \mathrm{I}(b)$, and 2.5 $\mu \mathrm{g}$ of U1$70 \mathrm{~K}(161-437)-\Delta \mathrm{I}$, with $2.5 \mu \mathrm{g}$ of IL-2 plasmid $(c)$. $(B)$ S1 nuclease protected nuclear (lanes $1,3,5)$ and cytoplasmic $($ lanes $2,4,6)$ RNA fragments, representing constructs shown in $A$, were analyzed as in Fig. 3B.

phosphorylated (data not shown). This result is compatible with the results of Gui et al. (1994) because overexpression of unphosphorylated U1-70K appeared to induce coalescence of the speckles.

It has been suggested that some SR proteins perform similar or redundant functions (Zahler et al. 1992), because they can each restore splicing to depleted extracts (Fu et al. 1992; Zahler et al. 1993) and participate in spliceosome assembly (Eperon et al. 1993; Fu 1993). The RS regions present in the splicing factors $s u\left(w^{a}\right), \mathrm{U} 2 \mathrm{AF}$, and $A S F / S F 2$ are similar to $\mathrm{RD} / \mathrm{RE} / \mathrm{RS}$ sequences in the carboxyl terminus of Ul-70K and have been implicated in protein-protein interactions. For example, fusion of the RS region of $s u\left(w^{a}\right)$ to an unrelated cytoplasmic protein targeted it to nuclear speckles ( $\mathrm{Li}$ and Bingham 1991). Also, deletion of the RS region of U2AF did not affect its binding to the RNA substrate, but in vitro splicing was inhibited (Zamore et al. 1992). Other recent evidence suggests that the RS region of U2AF is necessary for splicing to occur but only after U2AF binds to the pre-mRNA. Furthermore, placement of the RS region of U2AF into a non-SR protein, sex lethal (Sxl), converts it from a splicing repressor to a splicing activator (Valcarcel et al. 1993). In other studies, mutation of the RS region of ASF/SF2 was found to disrupt its constitutive splicing activity but did not appear to affect alternative splicing (Caceres and Krainer 1993; Zuo and Manley 1993). Given the ability of overexpressed U1-70K to colocalize with and redistribute SC-35 as demonstrated here, it is possible that U1-70K interacts electrostatically with some splicing factors to bridge donor and acceptor splice sites (Query et al. 1989a; Keene and Query 1991).

The observation that SC-35 and U1-70K colocalize in the same nuclear regions could be attributed to their direct association, which has been demonstrated in vitro (Wu and Maniatis 1993). Additional studies have shown that U1-70K can interact directly with ASF/SF2 and that the $\mathrm{RD} / \mathrm{RE} / \mathrm{RS}$ regions are required for this interaction (Kohtz et al. 1994). We we demonstrated previously that the $\mathrm{RD} / \mathrm{RE} / \mathrm{RS}$ regions of $\mathrm{Ul}-70 \mathrm{~K}$ did not associate in Ul snRNP particles when overexpressed in vivo by transient transfection (Romac et al. 1994). Thus, most of the overexpressed $\mathrm{U1}-70 \mathrm{~K}$ is not associated with U1 snRNPs because of its high level of expression but is still able to associate with the SR proteins. We propose that the absence of Ul snRNP in the "prespliceosomal com- 
Figure 8. Demonstration that overexpression of full-length U1-70K affects nucleocytoplasmic transport of polymerase II transcripts lacking the $5^{\prime}$ splice site $(A)$ or the intron $(B)$. Sl nuclease protection of RNA isolated from COS cells transfected with pBC-U1-70K $(A$, lanes $2,3)$; $(B$, lanes 3,4$)$ or $\mathrm{pBC}-\mathrm{U} 1-70 \mathrm{~K}(1-216)(A$, lanes 4,5$),(B$, lanes 5,6$)$. Protected nuclear $(A$, lanes 2,4$),(B$, lanes 3,5$)$, and cytoplasmic $(A$, lanes 3,5$),(B$, lanes 4,6$)$ RNA fragments were analyzed as in Fig. 3B.
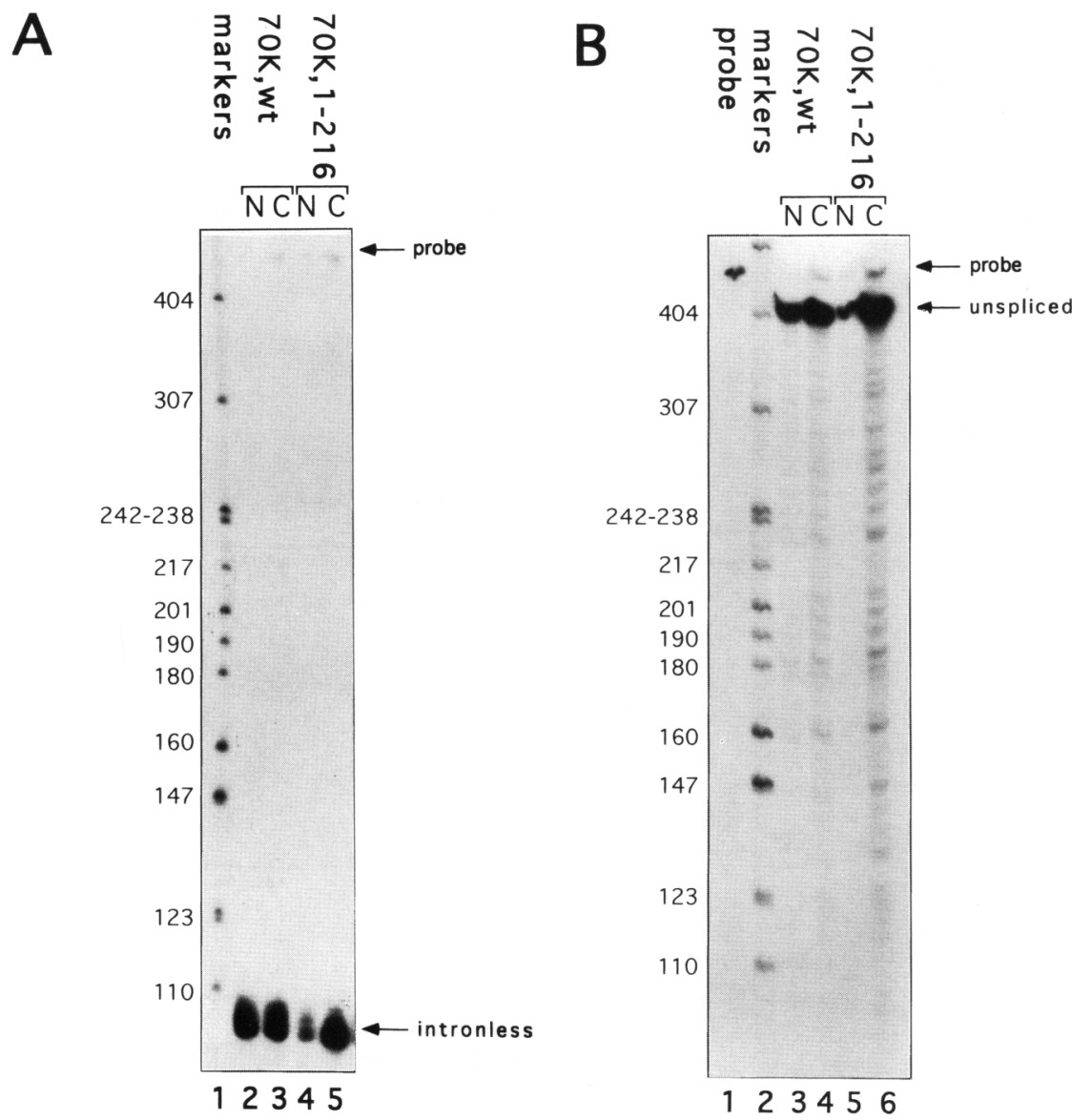

plex" prevented normal splicing processes. Such a model predicts that excess of U1-70K or the RD/RE/RS portion of U1-70K causes an imbalance of fully functional splicing components, thus limiting the flux of pre-mRNA through the splicing machinery. This model is consistent with the results of Staknis and Reed (1994), who found that levels of SR proteins affect the selection of $3^{\prime}$ and $5^{\prime}$ splice sites and are limiting for assembly of prespliceosomal complex E. In the case of the $5^{\prime}$ splice site, SC-35 was shown to stimulate binding of U1 snRNPs to purine-rich exonic enhancers. Similar results were shown for ASF/SF2 by Eperon et al. (1993) and Kohtz et al. (1994). Our data suggest that splicing and transport are inhibited by excess U1-70K because interactions among Ul snRNPs, SR proteins, and the premRNA are functionally disrupted.

\section{Materials and methods}

Plasmids and constructs

The pBC-U1-70K plasmid has been described elsewhere (Romac et al. 1994|. The polyadenylation site on the Ul-70K cDNA was removed by digesting the pBC-U1-70K plasmid with MluI-Sall and blunt-end ligation. The U1-70K deletion mutants $161-437,280-437$, and 1-216 have been described elsewhere (Query et al. 1989a). The 161-299 mutant was obtained by digesting the 161-437 construct with ApaI and BstEII and blunt ligation, which excised the rat PPI gene fragment. The 5' splice site and intronless constructs were obtained by digesting the plasmid with EcoRI and SmaI, respectively.

\section{Cell culture and transfection}

COS cells were maintained in Iscove's media with $10 \%$ fetal bovine serum and transfected either by the DEAE-dextran and the chloroquine method (Cullen 1987) or by lipofectase (GIBCO-BRL) with plasmid DNA at a concentration of 2.5 $\mu \mathrm{g} / \mathrm{ml}$.

\section{S1 nuclease protection analysis}

Cells were washed several times in cold PBS and harvested using a plastic scraper. Nuclear and cytoplasmic fractions were obtained by treating the cells with NP-40 lysis buffer for $5 \mathrm{~min}$ utes on ice (Greenberg and Ziff 1984), followed by centrifugation for $1 \mathrm{~min}$ at $14,000 \mathrm{rpm}$ in a microcentrifuge. One packed cell volume of $8 \mathrm{M}$ guanidine isothiocyanate was added to one volume of cytoplasmic extract. Nuclear pellets were resuspended in $1 \mathrm{ml}$ of $4 \mathrm{M}$ guanidium isothiocyanate and disrupted through a 27-gauge needle. RNAs from cytoplasmic and nuclear extracts were pelleted through a $5.7 \mathrm{M} \mathrm{CsCl}$ cushion by centrifugation for $3.5 \mathrm{hr}$ at $25^{\circ} \mathrm{C}$ in a TL55S rotor (Beckman). The pellets were then resuspended and stored in water. An aliquot was analyzed on an agarose gel for RNA integrity and yield.

A 459-bp probe that encompasses 267 bp of the intron and 129 bp of the second exon of the rat PPI II gene, obtained by sub- 


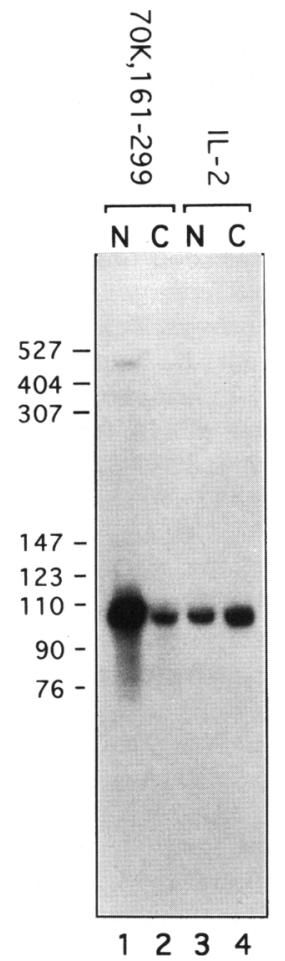

Figure 9. Demonstration that overexpression of the U1$70 \mathrm{~K}(161-299)$ fragment affects nucleocytoplasmic transport of polymerase II transcripts. Protected nuclear (lanes 1,3) and cytoplasmic $(2,4)$ transcripts following $\mathrm{S} 1$ nuclease analysis obtained from COS cells transfected with the pBC-Ul-70K/161299) (lanes 1,2) or a control pBC plasmid (lanes 3,4).

cloning its KpnI-EcoRI fragment into pGEM $3 z f|+|$ (Promega), was synthesized by the polymerase chain reaction using the $T 7$ oligonucleotide and an antisense oligonucleotide hybridizing to the exon sequences of the rat PPI gene. Prior to amplification, the antisense oligonucleotide was radiolabeled at its $5^{\prime}$ end with T4 kinase (U.S. Biochemical) and $\left[\gamma^{-32} \mathrm{P}\right]$ ATP. The S1 nuclease protection assay was performed as described (Berk and Sharp 1977), with the following modifications: The RNA-DNA complexes were hybridized at $55^{\circ} \mathrm{C}$ overnight and digested for $1 \mathrm{hr}$ at $37^{\circ} \mathrm{C}$. Protected fragments were $396 \mathrm{bp}$ in the case of unspliced message, $129 \mathrm{bp}$ in the case of the spliced message, $83 \mathrm{bp}$ when the DNA construct did not contain the intron sequence, and $100 \mathrm{bp}$ for the U1-70K(161-299) cDNA fragment that also lacked the intron.

Quantitation of gel bands utilized laser scanning densitometry (LKB) of the autoradiographs. Arbitrary values (AUxmm) of the integrated peak as presented in Results reflected the amount of protected mRNA fragment.

\section{Indirect immunofluorescence assay}

Cells were fixed $48 \mathrm{hr}$ post-transfection as described previously (Romac et al. 1994). When double immunofluorescence was performed, the fixed cells were incubated stepwise for $30 \mathrm{~min}$ at room temperature with either the SC-35 monoclonal antibody (gift of X.-D. Fu, University of California, San Diego) or hnRNP C monoclonal antibody (gift of G. Dreyfuss, University of Pennsylvania, Philadelphia) followed by affinity purified FITC-conjugated rabbit anti-mouse antibodies at a dilution of 200:1 (Jack- son Labs). Following this incubation, the rabbit anti-g10 antibody (Tsai et al. 1992) was incubated with the fixed cells. Finally, affinity-purified Texas Red-conjugated donkey anti-rabbit antibodies (Jackson Labs) were used at a dilution of 200:1. Slides were viewed on a Zeiss Axioskop microscope and recorded on Kodak Ektachrome 400. Single immunofluorescence stainings were recorded on Kodak T-max 400.

\section{Acknowledgments}

We thank Mike Malim and Laurence Rimsky for advice, and Ameeta Kelekar and Dragana Antic for comments on the manuscript. This work was supported by research grant CA60083 from the National Institutes of Health to J.D.K., and J.M.-J.R. was supported by Neurobehavioral training grant 5T32MH5177 and Viral Oncology training grant 5T32CA09111.

The publication costs of this article were defrayed in part by payment of page charges. This article must therefore be hereby marked "advertisement" in accordance with 18 USC section 1734 solely to indicate this fact.

\section{References}

Baker, B.S. 1989. Sex in flies: Splice of life. Nature 340: 521524.

Berk, A.J. and P.A. Sharp. 1977. Sizing and mapping of early adenovirus mRNAs by gel electrophoresis of $\mathrm{Sl}$ endonuclease-digested hybrids. Cell 12: 721-732.

Billings, P.B. and S.O. Hoch. 1984. Characterization of U small nuclear RNA-associated proteins. I. Biol. Chem. 259: 12850-12856.

Caceres, X.F. and A.R. Krainer. 1993. Functional analysis of pre-mRNA splicing factor SF2/ASF structural domains. EMBO I. 12: 4715-4726.

Carter, K.C., D. Bowman, W. Carrington, K. Fogarty, J.A. McNeil, F.S. Fay, and J.B. Lawrence. 1993. A three-dimensional view of precursor messenger RNA metabolism within the mammalian nucleus. Science 259: 1330-1334.

Choi, Y.D., P.J. Grabowski, P.A. Sharp, and G. Dreyfuss. 1986. Heterogeneous nuclear ribonucleoproteins: Role in RNA splicing. Science 231: 1534-1539.

Chou, T.B., Z. Zachar, and P.M. Bingham. 1987. Developmental expression of a regulatory gene is programmed at the level of splicing. EMBO I. 6: 4095-4104.

Cullen, B.R. 1986. Trans-activation of human immunodeficiency virus occurs via a bimodal mechanism. Cell 46: 973-982. - 1987. Use of eukaryotic expression technology in the functional analysis of cloned genes. Methods Enzymol. 152: 684-704.

Eperon, I.C., D.C. Ireland, R.A. Smith, A. Mayeda, and A.R. Krainer 1993. Pathways for selection of $5^{\prime}$ splice sites by Ul snRNP and SF2/ASF. EMBO I. 12: 3607-3617.

Fakan, S., G.P. Leser, and T.E. Martin 1984. Ultrastructural distribution of nuclear ribonucleoproteins as visualized by immunocytochemistry on thin sections. J. Cell Biol. 98: 358363.

Fu, X.-D. 1993. Specific commitment of different pre-mRNAs to splicing by single SR proteins. Nature 365: 82-85.

Fu, X.-D. and T. Maniatis. 1990. Factor required for mammalian spliceosome assembly is localized to discrete regions in the nucleus. Nature 343: 437-441.

Fu, X.-D., A. Mayeda, T. Maniatis, and A.R. Krainer. 1992. General splicing factors SF2 and SC35 have equivalent activities in vitro, and both affect alternative $5^{\prime}$ and $3^{\prime}$ splice site selection. Proc. Natl. Acad. Sci. 89: 11224-11228. 
Ge, H., P. Zuo, and J.L. Manley. 1991. Primary structure of the human splicing factor ASF reveals similarities with Drosophila regulators. Cell 66: 373-382.

Green, M.R. 1986. Pre-mRNA splicing. Annu. Rev. Genet. 20: 671-708.

Greenberg, M.E. and E.B. Ziff. 1984. Stimulation of 3T3 cells induces transcription of the c-fos proto-oncogene. Nature 311: 433-438.

Gui, J.-F., W.S. Lane, and X.-D. Fu. 1994. A serine kinase regulates intracellular localization of splicing factors in the cell cycle. Nature 369: 678-682.

Huang, S. and D.L. Spector. 1992. U1 and U2 small nuclear RNAs are present in nuclear speckles. Proc. Natl. Acad. Sci. 89: 305-308.

Keene, J.D. and C.C. Query. 1991. Nuclear RNA-binding proteins. In Prog. Nucleic Acids Res. Mol. Biol. 41: 179-201.

Kohtz, J.D., S.F. Jamison, C.L. Will, P. Zuo, R. Luhrmann, M.A. Garcia-Blanco, and J.L. Manley. 1994. Protein-protein interaction and $5^{\prime}$ splice site recognition in mammalian mRNA precursors. Nature 368: 119-124.

Krainer, A.R., A. Mayeda, D. Kozak, and G. Binns. 1991. Functional expression of cloned human splicing factor SF2: Homology to RNA-binding proteins, U1 $70 \mathrm{~K}$, and Drosophila splicing regulators. Cell 66: 383-394.

Lerner, E.A., M.R. Lerner, C.A. Janeway, and J.A. Steitz. 1981. Monoclonal antibodies to nucleic acid-containing cellular constituents: Probes for molecular biology and autoimmune disease. Proc. Natl. Acad. Sci. 78: 2737-2741.

Li, H. and P.M. Bingham. 1991. Arginine/serine rich domains of the su( $\left.w^{\mathrm{a}}\right)$ and tra RNA processing regulators target proteins to a subnuclear compartment implicated in splicing. Cell 67: 335-342.

Moore, M.J., C.C. Query, and P.A. Sharp. 1993. Splicing of precursors to mRNA by the spliceosome. In The RNA world led. R.F. Gesteland and J.F. Atkins|, pp. 303-357. Cold Spring Harbor Laboratory Press, Cold Spring Harbor, New York.

O'Keefe, R.T., A. Mayeda, C.L. Sadowski, A.R. Krainer, and D.L. Spector. 1994. Disruption of pre-mRNA splicing in vivo results in reorganization of splicing factors. $J$. Cell Biol. 124: 249-260.

Petterson, I., M. Hinterberger, T. Mimori, E. Gottlieb, and J.A. Steitz. 1984. The structure of mammalian small nuclear ribonucleoproteins. J. Biol. Chem. 259: 5907-5914.

Query, C.C., R.C. Bentley, and J.D. Keene. 1989a. A common RNA recognition motif identified within a defined UI RNA binding domain of the 70K U1 snRNP protein. Cell 57: 89101.

- 1989b. A specific 31-nucleotide domain of U1 RNA directly interacts with the $70 \mathrm{~K}$ small nuclear ribonucleoprotein component. Mol. Cell. Biol. 9: 4872-4881.

Reich, C.I., R.W.V. Hay, G.L. Porter, and J.A. Wise. 1992. Mutations at the $3^{\prime}$ splice site can be supported by compensatory base changes in U1 snRNA in fission yeast. Cell 69: 1159-1169.

Romac, J.J.-M., D.H. Graff, and J.D. Keene. 1994. Ul snRNP 70K is transported independently of U1 snRNP particles via a nuclear localization signal in the RNA binding domain. Mol. Cell. Biol. 14: 4662-4670.

Rosbash, M. and R.H. Singer. 1993. RNA travel: Tracks from DNA to cytoplasm. Cell 75: 399-401.

Spector, D.L. 1990. Higher order nuclear organization: Threedimensional distribution of small nuclear ribonucleoprotein particles. Proc. Natl. Acad. Sci. 87: 147-151.

Spector, D.L., X.-D. Fu, and T. Maniatis. 1991. Associations between distinct pre-mRNA splicing components and the cell nucleus. EMBO $J$. 10: 3467-3481.
Staknis, D. and R. Reed. 1994. SR proteins promote the first specific recognition of pre-mRNA and are present together with the Ul small Nuclear Ribonucleoprotein Particle in a general splicing enhancer complex. Mol. Cell. Biol. 14: 7670-7682.

Steitz, J.A., D.L. Black, V. Gerke, K.A. Parker, A. Kramer, D. Frendewey, and W. Keller. 1988. Functions of abundant U-snRNPs. In structure and function of major and minor small nuclear ribonucleoprotein particles led. M.L. Birnstiel), pp. 115-154. Springer, Berlin/New York.

Theissen, H., M. Etzerodt, R. Reuter, C. Schneider, F. Lottspeich, P. Argos, R. Luhrmann, and L. Phillipson. 1986. Cloning of the human cDNA for the Ul RNA-associated $70 \mathrm{~K}$ protein. EMBO I. 5: 3209-3217.

Tsai, D.S., D.J. Kenan, and J.D. Keene. 1992. In vitro selection of an RNA epitope immunologically cross reactive with a peptide. Proc. Natl. Acad. Sci. 89: 8864-8868.

Valcarcel, J., R. Singh, P.D. Zamore, and M.R. Green. 1993. The protein sex-lethal antagonizes the splicing factor U2AF to regulate alternative splicing of transformer pre-mRNA. $\mathrm{Na}$ ture 362: 171-175.

Wang, J., L.-G. Lao, Y.-L. Wang, and T. Pederson. 1991. Localization of pre-messenger RNA at discrete nuclear sites. Proc. Natl. Acad. Sci. 88: 7391-7395.

Wansink, D.G., W. Schul, I. van der Kraan, B. van Steensel, R. van Driel, and L. de Jong. 1993. Fluorescent labeling of nascent RNA reveals transcription by RNA polymerase II in domains scattered throughout the nucleus. J. Cell Biol. 122: 283-293.

Wooley, J.C., L.R. Zukerberg, and S.-Y. Chung. 1983. Polypeptide components of human small nuclear ribonucleoproteins. Proc. Natl. Acad. Sci. 80: 5208-5212.

Woppmann, A., Q. Will, U. Kornstadt, P. Zuo, J.L. Manley, and R. Luhrmann. 1990. Identification of an snRNP-associated kinase activity that phosphorylates arginine/serine rich domains typical of splicing factors. Nucleic Acids Res. 18: $4427-4438$

Wu, J.Y. and T. Maniatis. 1993. Specific interactions between proteins implicated in splice site selection and regulated alternative splicing. Cell 75: 1061-1070.

Xing, Y., C.V. Johnson, P.R. Dobner, and J.B. Lawrence. 1993. Higher level organization of individual gene transcription and RNA splicing. Science 259: 1326-1330.

Zachar, Z., T.-B. Chou, and P.M. Bingham. 1987. Evidence that a regulatory gene autoregulates splicing of its transcripts. EMBO I. 6: 4105-4111.

Zahler, A.M., W.S. Lane, J.A. Stolk, and M.B. Roth. 1992. SR proteins: A conserved family of pre-mRNA splicing factors. Genes \& Dev. 6: 837-847.

Zahler, A.M., K.M. Neugebauer, J.A. Stolk, and M.B. Roth 1993. Human SR proteins and isolation of cDNA encoding SRp75. Mol. Cell. Biol. 13: 4023-4028.

Zamore, P.D., J.G. Patton, and M.R. Green. 1992. Cloning and domain structure of the mammalian splicing factor U2AF. Nature 355: 609-614.

Zhang, M., P.D. Zamore, M. Carmo-Fonseca, A.I. Lamond, and M.R. Green. 1992. Cloning and intracellular localization of the U2 small nuclear ribonucleoprotein auxiliary factor small subunit. Proc. Natl. Acad. Sci. 89: 8769-8773.

Zuo, P. and J.L. Manley. 1993. Functional domains of the human splicing factor ASF/SF2. EMBO I. 12: 4727-4737. 


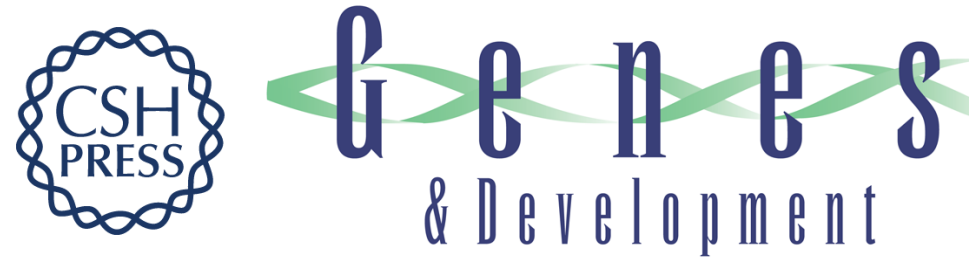

\section{Overexpression of the arginine-rich carboxy-terminal region of $\mathrm{U} 1$ snRNP 70K inhibits both splicing and nucleocytoplasmic transport of mRNA.}

J M Romac and J D Keene

Genes Dev. 1995, 9:

Access the most recent version at doi:10.1101/gad.9.11.1400

References This article cites 49 articles, 21 of which can be accessed free at:

http://genesdev.cshlp.org/content/9/11/1400.full.html\#ref-list-1

License

Email Alerting Receive free email alerts when new articles cite this article - sign up in the box at the top Service right corner of the article or click here.

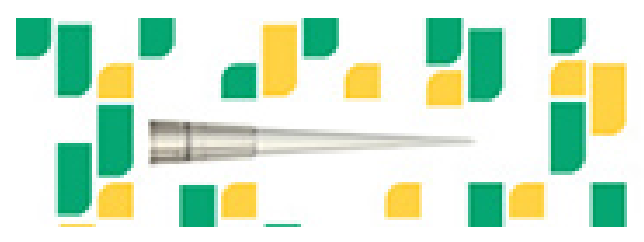

Focused on your science. 